\title{
LEO STRAUSS AND THE CHARACTER OF ClASSICAL POLITICAL PHILOSOPHY *
}

\author{
Leo Strauss e a Natureza da Filosofia Política Clássica
}

Richard Romeiro Oliveira **

Abstract: This paper aims to present Leo Strauss's interpretation of the meaning of classical political philosophy. To this end, the paper will try to show how, for Strauss, classical political philosophy, emerging from the original conflict that opposes philosophic reason to the authorized opinions of the city, was organized as a fundamentally esoteric teaching that sought to make the practical and moral demands of political life, expressed exemplarily in the ideal of best regime, compatible with the defense of contemplative life as the most perfect and happy life for man.

Key-words: Esotericism. Opinion. Political Life. Best Regime. Contemplation.

Resumo: O principal objetivo deste artigo é apresentar a interpretação elaborada por Leo Strauss acerca do significado da filosofia política clássica. Com esse intuito, o artigo tentará mostrar como, para Strauss, a filosofia política clássica, emergindo a partir do conflito originário que opõe a razão filosófica às opiniões autorizadas da cidade, organizou-se como um ensinamento fundamentalmente esotérico que buscou compatibilizar as exigências práticas e morais da vida política, expressas exemplarmente no ideal do melhor regime, com a defesa da vida contemplativa como a vida mais perfeita e feliz para o homem.

Palavras-chave: Esoterismo. Opinião. Vida Política. Melhor Regime. Contemplação.

* Artigo recebido em 21/08/2020 e aprovado para publicação em 15/01/2021.

** Doutor em Filosofia pela Universidade Federal de Minas Gerais. Professor do Departamento de Filosofia da Universidade Federal de São João del-Rei. 


\section{The Literary Art of Esotericism and the Original Meaning of Political Philosophy in Ancient Thought}

$\mathrm{s}$ is well known, Leo Strauss devoted a good part of his intellectual
production to the development of a scholarly and painstaking un-
derstanding of the fundamental teachings of classical philosophy, i. e., of that specific form of philosophic thought that has prevailed in the ancient world. Yet Strauss was not a conventional scholar, and his interest in ancient thought was far from being merely historical or derived from pure archeological curiosity. In fact, by recovering the study of the classical authors, the primeval Straussian purpose consisted in trying to bring to light again what was the original position of philosophy in order to thereby access the type of intellectual attitude that would have been characteristic of this position towards both knowledge and social life and its practical issues. Strauss's assumption is that from the achievement of this procedure it will become once more possible to observe the extent to which the original position of philosophy, as ancient authors articulated it, might be yet seen as a legitimate alternative to the theoretical postulates adopted by that intellectual movement which is, in Strauss's view, the most powerful of our time: historicism. ${ }^{1}$ This means that the Straussian resumption of the investigation of the classical books is part of an ambitious project whose aim is nothing less than to rethink the nature of philosophy in a radical and deliberate confrontation with the new speculative assumptions adopted by modern and contemporary thought. ${ }^{2}$ Well, a pivotal part of Strauss's

\footnotetext{
${ }^{1}$ In What is Political Philosophy? (Chicago: University of Chicago Press, 1988 [1959]), p. 57 (hereafter cited WPP), Strauss stated the indisputable predominance of historicism over the contemporary intellectual life as follows: “[...] historicism is not just one philosophic school among many, but a most powerful agent that affects more or less all present-day thought. As far as we can speak at all of the spirit of a time, we can assert with confidence that the spirit of our time is historicism." On the Straussian concern with what would have been the "original position of philosophy" in ancient thought, see the valuable remarks of Steven B. Smith, "Philosophy as a Way of Life: The Case of Leo Strauss," in Political Philosophy in the Twentieth Century, ed. Catherine Zuckert (Cambridge: Cambridge University Press, 2011), p. 77. ${ }^{2}$ Concerning Strauss's intent to call into question the intellectual assumptions assumed by modern and contemporary thought through the recovering of the original meaning of philosophy, see the valuable remarks stated by Ted V. McAllister, Revolt Against Modernity: Leo Strauss, Eric Voegelin, and the Search for a Postliberal Order (Lawrence: University Press of Kansas 1995), p. 193-195. According to Allan Bloom, we find here a decisive point to understand the general character of Strauss's thinking since the obstinate meditation on what philosophy ultimately is constitutes the unifying element that permeates Strauss's work on its whole. As Bloom explains, "[a] survey of Strauss' entire body of work will reveal that it constitutes a unified and continuous, ever deepening investigation into the meaning and possibility of philosophy. It is the product of a philosophic life devoted to an understanding of the philosophic life at a time when philosophy can no longer give an account of itself and the most modern philosophers have abandoned reason, and hence philosophy, in favor of will or commitment. It is an investigation carried on in light of the seriousness of the objections and their proponents." ("Leo Strauss. September 20, 1889 - October 18, 1973," Political Theory, vol. 2, n. 4 [1974]: 376).
} 
interpretation of the meaning of ancient philosophy rests on the idea that this philosophy was, in general, marked by a decisive political experience, which defined its most characteristic intellectual physiognomy and the peculiar form of writing and communication through which it was often expressed. What experience was that? Simply put, this experience consisted, in Strauss's eyes, in the acute awareness of the radically problematic and even conflicting character of the relations between philosophy and civil society (or, if we prefer, between philosophy and the city). ${ }^{3}$

Strauss explains the origin of this conflict, whose apprehension lies at the very heart of ancient thought, as a consequence of the defiant and insubordinate nature of philosophy. According to him, in effect, while the ordinary life of civil society requires, on its very basis, the existence of authorized opinions (dóxai), that is, the existence of a set of beliefs concerning the most important things explicitly or implicitly sanctioned by the established power, philosophy intends to be precisely the attempt to transform opinions about the most important things into knowledge of the most important things. From the Straussian perspective, this means that philosophy has a necessarily disruptive character towards the established political order, insofar as it involves as its deepest intellectual drive the bold intention of destroying the principle that functions as the element of all ordinary social life: opinion. ${ }^{4}$ Philosophy thus understood is therefore "essentially subversive" and involves the practice of an unorthodox and anti-doxastic thinking that somehow conflicts with the city and its order. ${ }^{5}$ It follows from this that for Strauss, as Pangle rightly explains, the philosophic activity can be conceived by its very nature as a genuine "rebellion against the spiritual authority of civil society." ${ }^{6}$

By taking these elements into account one can then understand why there is, according to Strauss, "a disproportion between the intransigent quest for the truth [aimed by philosophy] and the requirements of society." ${ }^{7}$

\footnotetext{
${ }^{3}$ According to Corine Pelluchon, for Strauss this conflict cannot, after all, be resolved because "il ne peut y avoir de reconciliation entre la pensée et l'action. La tension entre la philosophie et la Cité est l'objet même de la réflexion philosophique." (Leo Strauss: une autre raison, d'autres Lumières. Essai sur la crise de la rationalité contemporaine [Paris: J. Vrin, 2005], p. 218). ${ }^{4}$ STRAUSS, Leo. WPP, p. 11; 221.

${ }^{5}$ In an unpublished lecture entitled "Reason and Revelation (1948)," in Leo Strauss and the Theologico-Political Problem, by Heinrich Meier (Cambridge, UK: Cambridge University Press, 2006), p. 146, Strauss explicitly states the subversive character of philosophy in the following terms: "If opinions are the element of society, philosophy, which questions opinions as such, dissolves the very element of social life: philosophy is essentially subversive (corrupting the young)."

${ }^{6}$ PANGLE, Thomas L. "Introduction," in Studies in Platonic Political Philosophy, by Leo Strauss (Chicago: University of Chicago Press, 1983), p. 10 (hereafter cited as SPPP). On this subject, see also Steven B. Smith, "Philosophy as a Way of Life: The Case of Leo Strauss," p. 69-70. ${ }^{7}$ STRAUSS, Leo. On Tyranny. Corrected and expanded edition. Including the Strauss-Kojève correspondence. Edited by Victor Gourevitch \& Michael S. Roth (Chicago: University of Chicago Press, 2013 [1961]), p. 27 (hereafter cited as OT).
} 
This means, in Strauss's eyes, that a real tension takes place between the intellectual operation achieved through the exercise of philosophic activity and what is necessary for the preservation of social order, a tension which, as Smith noted, "constitutes the political situation of philosophy."

In many of his works, Strauss emphasizes that the classical philosophers (and their spiritual heirs in the Middle Ages, like Farabi or Maimonides, for example) have realized this tension very well and understood therefore the politically problematic nature of philosophy. Because of that, these philosophers were led then to work out a new literary technique - the esoteric writing - designed to neutralize the destructive impact of philosophic teaching about the authoritative opinions that sustains the social life and avoid thereby eventual persecutions unleashed against them by political and religious authorities. ${ }^{9}$ According to Strauss, the fundamental procedure of this new literary technique consisted in the art of "writing between the lines," i. e., in the art of concealing the potentially subversive teachings of an author under the guise of politically harmless statements. ${ }^{10}$ This means, from the Straussian perspective, that a text which uses the art of "writing between the lines" will necessarily contain two kinds of teachings: one of a popular and exoteric character, made up of assertions according to the accepted opinions and intended for the unphilosophic multitude; and another of esoteric character, containing subversive or heterodox statements and intended only for the most intellectually prepared readers, who can as such become philosophers. ${ }^{11}$ The crucial point here is that this distinction between exoteric and esoteric teachings - a distinction that is of ultimate importance to understand ancient books - rests, in Strauss's view, on the fact that there is an irreducible difference between two different audiences: the many who are careless readers and who can be satisfied with socially useful opinions, and the few who are thoughtful or careful readers and who can therefore assimilate the unorthodox truths of philosophy. In his essay "On a forgotten kind of writing," Strauss brings this point to light, explaining that the writers who use esoteric writing "will distinguish between the true teaching as the esoteric teaching and the socially useful teaching as the exoteric teaching; whereas the exoteric teaching is meant to be easily accessible to every reader, the esoteric teaching discloses itself only to very careful and well trained readers after long and concentrated study." 12

\footnotetext{
${ }^{8}$ SMITH, Steven B. "Philosophy as a Way of Life: The Case of Leo Strauss," p. 70.

${ }^{9}$ On this subject, see Leo Strauss, Persecution and the Art of Writing (Chicago: University of Chicago Press, 1988 [1952]. Hereafter cited as PAW). In the preface to this book (p. 5), Strauss clarifies that the fundamental problem by him investigated throughout the book is "the problem of the relation between philosophy and politics." Later (p. 95), at the beginning of a chapter dedicated to the analysis of the Kuzari, the most famous work of the medieval Jewish philosopher Yehuda Halevi, he emphasizes the importance of this question and observes that the proper understanding of "what a philosopher is" depends, in the last analysis, on the understanding of "the relation of philosophy to social or political life."

${ }^{10}$ PAW, p. 24-25.

${ }^{11}$ PAW, p. 36.

${ }^{12}$ WPP, p. 222.
} 
In Persecution and the Art of Writing, through the careful analysis of the comments of the medieval Arab philosopher Farabi on the true meaning of Plato's teaching, Strauss points out that the origin of this literary procedure goes back to the Greek philosopher, who was faced with the lack of "freedom of teaching and research" in the cities of his time. Taking this approach further, Strauss explains that such a form of writing was needed to protect philosophy from social persecution since philosophers were considered in the ancient world as mavericks, so to speak, and were therefore regarded with profound suspicion. From the Straussian perspective, this fact demonstrates that, in Classical antiquity, philosophers had an extremely precarious political status, which makes it clear that, at that historical moment, there was "no harmony between philosophy and society." Due to this problem, "exoteric literature" was precisely devised by Plato and other philosophers as a technique of presenting philosophy before the city in a more acceptable way and, what is more important, in accordance with the opinions of the city. As such, "exoteric literature" constituted the political aspect of philosophy or even political philosophy itself, as Strauss explicitly declares:

What Farabi indicates in regard to the procedure of the true philosophers, is confirmed by a number of remarks about the philosophic distinction between the exoteric and the esoteric teaching which occur in the writings of his successors. Farabi's Plato informs us about the most obvious and the crudest reason why this antiquated or forgotten distinction was needed. Philosophy and the philosophers were "in grave danger": Society did not recognize philosophy or the right of philosophizing. There was no harmony between philosophy and society. The philosophers were very far from being exponents of society or of parties. They defended the interests of philosophy and of nothing else. In doing this, they believed indeed that they were defending the highest interests of mankind. The exoteric teaching was needed for protecting philosophy. It was the armor in which philosophy had to appear. It was needed for political reasons. It was the form in which philosophy became visible to the political community. It was the political aspect of philosophy. It was "political" philosophy. ${ }^{13}$

\footnotetext{
${ }^{13}$ PAW, p. 17-18. In his essay "On Classical Political Philosophy," in WPP, p. 93, Strauss emphasizes once again the politically precarious status of ancient philosophers, declaring that in the Greek city "the meaning of philosophy was by no means generally understood, and hence philosophy was distrusted and hated by many well-meaning citizens. Socrates himself fell victim to the popular prejudice against philosophy." See also what Strauss says in his essay "Farabi's Plato," in Louis Ginzberg Jubilee Volume. New York, American Academy for Jewish Research, 1945, p. 382: "The philosopher necessarily lives in political society, and he thus cannot escape the situation created by the naturally difficult relations between the philosopher and the non-philosophic citizens: 'the vulgar.' The philosopher living in a society which is not ruled by philosophers, i. e. the philosopher living in an actual society, is necessarily 'in grave danger."' According to Steven B. Smith, Strauss thinks that this danger concerning the "society's hostility to philosophy" is something "coeval with philosophy." ("Philosophy as a Way of Life: The Case of Leo Strauss," p. 73, n. 40).
} 
As Lefort remarks, what Strauss intends to express by utterances like these is that political philosophy is originally distinguished by "the way in which philosophy proceeds in order to find public expression" rather by its subject matter ("the nature of political things"). ${ }^{14}$ This is what Strauss himself makes clear by stating that "'political philosophy' means primarily, in the premodern world, not the philosophic treatment of politics but the political, or popular, treatment of philosophy, or the political introduction to philosophy." 15 In other words, in Strauss's view, political philosophy is not, in its most primal expression in ancient thought, the theoretical effort to subsume and integrate political life into the rational schemes of philosophic explanation, but rather the attempt to give philosophy an acceptable political appearance, i. e., an appearance which is politically in line with the city's moral requirements. This implies that the problem of political philosophy is at first, from the Straussian perspective, as Pangle rightly observes, "a problem of communication, of rhetoric," which finds its proper resolution in esoteric writing. ${ }^{16}$

From the observations developed above, we can therefore see that for Strauss the use of esoteric writing made by classical authors (and by medieval ones too), with the related development of a political treatment of philosophy, was not an artificial complication, derived from a literary caprice, but rather a practical and rhetorical necessity, resulting from the problematic political

${ }^{14}$ LEFORT, Claude. "Three Notes on Leo Strauss," in Writing the Political Text, by Claude Lefort. Trans. David Ame Curtis. (Durham, London: Duke University Press, 2000), p. 172.

${ }^{15}$ WPP, p. 93.

${ }^{16}$ PANGLE, Thomas L. "Editor's Introduction," in The Rebirth of Classical Political Rationalism, by Leo Strauss, ed. Thomas Pangle (Chicago: University of Chicago Press, 1989), p. xviii (hereafter cited as $R C P R$ ). Taking into account this Straussian conception of political philosophy in classical thought as "the political, or popular, treatment of philosophy," Catherine and Michael Zuckert explain in their article "Leo Strauss et le problème de la philosophie politique," in Leo Strauss. À quoi sert la philosophie politique, ed. F. Coppens et al. (Paris: PUF, 2014), p. 19, that, according to Strauss, political philosophy, in its origins, is not but the "aspect" that philosophy takes on vis-à-vis ordinary human existence, i. e., visà-vis nonphilosophic human existence. It must be noted here that the position adopted by Strauss concerning the problem of what would have been political philosophy in its original meaning, i. e., as it was elaborated by the classical authors, a position that understands the political character of philosophy as something related basically to its method of communication and therefore to its rhetorical form, is radically opposed to Kojève's position, for whom philosophy is essentially political since, for Kojève, whose theoretical assumptions are found in Hegel and Marx, philosophy demonstrates the truth of its tenets by becoming historically and socially effective. See, on this issue, Kojève's essay 'Tyranny and Wisdom" and Strauss's reply to Kojève's formulations entitled "Restatement on Xenophon's Hiero" in OT, p. 135-220. Regarding the difference between Strauss and Kojève as to the nature of the relations between philosophy and politics, Victor Gourevitch and Michael S. Roth remark in the 'Introduction' to OT, p. xix, that while for Strauss "it is primarily the manner of philosophy that is political," for Kojève "it is just as much its matter." Robert Pippin, in his article "Being, Time, and Politics. The Strauss-Kojève Debate," Political Theory, vol. 20, n. 3 (1992): 152-153, also emphasizes the radically politicized conception of philosophy in Kojève's teaching. 
situation of philosophy. However, Strauss thinks that, although this kind of writing was widely used in the past, it is no longer taken into account by modern scholarship and practically fell into oblivion in our days, thanks partly to the success of the modern philosophic enterprise, whose aim was precisely to overcome the old esotericism practiced by the best writers of the past and transform philosophy into a politically diffuse and radically public activity. ${ }^{17}$ Accordingly, because of this oblivion that affects the modern scholarship, he saw his rediscovery of esotericism as an outstanding achievement of his historical research. Yet, at the same time, he was perfectly aware of the controversial character of such achievement, mostly because it involves the acknowledgment that the ancient authors practiced a deliberate "economy of truth" that does not seem to harmonize quite well with the modern requirement of "transparency" that rules public communication nowadays, requirement that as such has become an unquestionable principle of contemporary liberalism. ${ }^{18}$ In Strauss's words: "Every decent modern reader is bound to be shocked by the mere suggestion that a great man might have deliberately deceived the large majority of his readers." ${ }^{19}$

Be this as it may, the point to be highlighted is that if we subject the Straussian analysis of the literary phenomenon of esotericism to closer examination, we realize that, in Strauss's eyes, ancient philosophers were led to develop "exoteric teaching" not only because they wanted to protect philosophy of political persecution but also because they wanted to safeguard society from the intransigent questioning of philosophy. For Strauss, this small but significant detail reveals a fundamental truth about the nature of philosophy, namely, the fact that philosophy, far from being a harmless or innocuous activity, which as such would be devoid of disturbing political effects, represents rather an intellectual demeanor that really "endangers society." That is why society must be somehow safeguarded from the harmful impact of philosophic inquiry. ${ }^{20}$ Smith draws our attention to this crucial feature of the Straussian understanding of the esoteric writing, observing that, according to Strauss, "[...] esoteric writing was practiced by those writers who wished not just to protect themselves from persecution but who wish to protect society from the dangers always inherent in philosophy." ${ }^{21}$ Therefore, philosophy is not

\footnotetext{
${ }^{17}$ See what Strauss asserts at the beginning of his article "Exoteric Teaching," in RCPR, p. 63. ${ }^{18}$ The expression "economy of truth" to designate the concealment strategy put into practice by exoteric literature occurs in $P A W$, p. 35.

${ }_{19} P A W$, p. 35. Regarding the controversial character of the Straussian "recovery" of the esoteric writing, see Catherine and Michael Zuckert, The Truth About Leo Strauss: Political Philosophy and American Democracy (Chicago: University of Chicago Press 2006), p. 42, and Steven B. Smith, "Leo Strauss Today," in The Cambridge Companion to Leo Strauss, ed. Steven B. Smith (Cambridge: Cambridge University Press, 2009), p. 3.

${ }^{20} W P P$, p. 211.

${ }^{21}$ SMITH, Steven B. "Leo Strauss: Between Athens and Jerusalem," The Review of Politics, vol. 53, no. 1 (1991): 92. Cf. also Thomas L. Pangle, Leo Strauss: An Introduction to his Thought and Intellectual Legacy (Baltimore, Maryland: The Johns Hopkins, 2006), p. 55-56.
} 
an inoffensive practice, and Strauss emphasizes that all the premodern authors' literary production was marked by the acute awareness of this important social phenomenon - namely, the dangerous and politically harmful character of the philosophic activity. ${ }^{22}$ Tanguay highlights this decisive topic in Strauss's understanding of ancient and medieval philosophy by remarking that, in Strauss's view, "ancient and medieval philosophers possessed a lively sense of the danger that philosophy could pose to the city." ${ }^{23}$ Hence, through esoteric writing understood as the peculiar way of communicating subversive philosophic teachings in a covert or disguised manner, these philosophers would have sought to bring about in the last analysis two principal and articulated goals: on the one hand, they intended to defend themselves from possible political persecution occasioned by their intransigent questioning of authoritative opinions; on the other hand, they wished to defend society from the corrosive character of philosophic criticism. ${ }^{24}$

\section{The Theological-political Problem and the Prudential Attitude of Classical Philosophy Towards the Divine Law and the Religion of the City}

Before proceeding with our explanation, we need to examine a little closer a pivotal aspect, in Strauss's perspective, of the phenomenon concerning the conflict between philosophy and society - a phenomenon that, as we have seen, reveals the politically harmful nature of philosophy and whose occurrence is responsible for the development of the technique of esoteric writing by the premodern authors. To say everything without further ado, this aspect of the phenomenon concerning the conflict between philosophy

\footnotetext{
${ }^{22}$ In the introduction to OT, Strauss notes that the need for Socratic rhetoric (another name for exoteric literature) practiced by Plato and Xenophon in their texts stems precisely from the potentially harmful character of truth to ordinary social life: "Socratic rhetoric is emphatically just. It is animated by the spirit of social responsibility. It is based on the premise that there is a disproportion between the intransigent quest for truth and the requirements of society, or that not all truths are always harmless." (OT, p. 27).

${ }^{23}$ TANGUAY, Daniel. Leo Strauss: An Intellectual Biography. Transl. Christopher Nadon (New Haven, CT: Yale University Press, 2007), p. 118.

${ }^{24}$ Cf. WPP, p. 212; PAW, p. 33-37. On the question of esotericism in Strauss, see Ted V. McAllister, Revolt Against Modernity, p. 86-94; Claude Lefort, "Three Notes on Leo Strauss," p. 172-178; Corine Pelluchon, Leo Strauss: une autre raison, d'autres Lumières, p. 16; Catherine and Michael Zuckert, The Truth About Leo Strauss, p. 41-44; Thomas L. Pangle, Leo Strauss: An Introduction to his Thought and Intellectual Legacy, p. 56-65; Daniel Tanguay, Leo Strauss: An Intellectual Biography, p. 69-80; Steven B. Smith "Leo Strauss Today," p. 3; and Mark Lilla, The Shipwrecked Mind. On Political Reaction (New York: New York Review Books, 2016), 50-52. It is worth noting here that the most complete and scholarly study of the literary phenomenon of esotericism in Western thought available today is that of Arthur M. Meltzer, Philosophy Between the Lines. The Lost History of Esoteric Writing (Chicago: University of Chicago Press, 2014).
} 
and society is something that has to do, according to Strauss, with religion, the utmost authority over human life in the ancient and medieval societies. As is known, in the ancient and medieval societies, all political authority was based, in effect, on religious beliefs, receiving hence from religion the sacred and transcendent sanction of its legal and moral rules. ${ }^{25}$ For Strauss, this means that the kind of authority that prevailed in the premodern communities and which was responsible for preserving civic order was that of a theological type, so that the original conflict between philosophy and society can be more rightly understood ultimately as the conflict between philosophy and theological power.

Strauss explains this point as follows: in a prephilosophic world, or in societies still ruled by the power of tradition, where the philosophic reason does not influence social life, the authority of political society is based on the belief that the moral order embodied in it is the "right way" or the "right custom" not only because this order is "our way" or "our custom," but also because it is conceived as the oldest one. This means that in the traditional city a prejudice against novelty prevails everywhere, so that the prestige of the oldness triumphs without dispute, a fact that leads to the ultimate identification of the political good with the ancestral. ${ }^{26}$ Yet Strauss goes further and remarks that, in the eyes of the prephilosophic mind, in order for the ancestral to be effectively the best, it is not enough for it to be the oldest: it must also be divine. That is why in a traditional city the ancestors were conceived as gods or as sons of gods or at least as men who lived close to the gods and who hence received from the gods the revelation of the "right way," which is thus imposed as "divine law." Strauss draws our attention to this essential point in another passage of Natural Right and History that is worth quoting here:

Prephilosophic life is characterized by the primeval identification of the good with the ancestral. Therefore, the right way necessarily implies thoughts about ancestors and hence about the first things simply. For one cannot reasonably identify the good with the ancestral if one does not assume that the ancestors were absolutely superior to "us," and this means that they were superior to all ordinary mortals: one is driven to believe that the ancestors, or those who established the ancestral way, were gods or sons of gods or at least "dwelling near the gods." The identification of the good with the

\footnotetext{
${ }^{25}$ With respect to the analysis of this phenomenon in the ancient world, the classical work is that of Fustel de Coulanges, La cité antique, which, despite being outdated nowadays with regard to specific historiographical details (the first edition of the book is from 1864), remains relevant concerning its main thesis, namely, that the social and political organization of the ancient city derived from religious beliefs. As Fustel de Coulanges asserts, "l'idée religieuse a été chez les Anciens le souffle inspirateur et organisateur de la societé." (La cité antique. Étude sur le culte, le droit, les institutions de la Grèce et de Rome [New York: Cambridge University Press, 2009], p. 164).

${ }^{26}$ STRAUSS, Leo. Natural Right and History (Chicago: University of Chicago Press, 1971 [1953]), p. 83 (hereafter cited as NRH).
} 
ancestral leads to the view that the right way was established by gods or sons of gods or pupils of gods: the right way must be a divine law. ${ }^{27}$

Strauss's statements are unambiguous and explain that in a traditional society, since "the right way must be a divine law," all community life has a theological foundation, which produces an essential symbiosis between politics and religion at the very basis of this type of society. ${ }^{28}$ As a matter of fact, Strauss sees this symbiosis not only as a feature of traditional societies but as a fundamental phenomenon of political life as such, which therefore would subsist in one way or another despite all historical changes. This means that, from the Straussian perspective, there is a certain dependence of social life on religion. The crucial point here, as Lilla explains, is that for Strauss, "without authoritative assumptions regarding morality and mortality, which religion can provide, no society can hold itself together." ${ }^{29}$ It follows from this that if philosophy, as we have seen, is "a rebellion against the spiritual authority of civil society," insofar as it intends to question the authoritative opinions on which civil society is based, it is also eo ipso a rebellion against the religious beliefs with which the authority of civil society is associated to legitimize itself. ${ }^{30}$ To put it another way, philosophy's subversion of the spiritual authority of civil society is ultimately a revolt against the theological power without which civil society cannot subsist, a revolt thus against the "divine law."

Now, according to Strauss, this complex political phenomenon, concerning the conflict between philosophy and the divine law of the city, brings to light the most fundamental opposition confronting human thought namely, the opposition between a way of life based on the belief in the need of a divine guidance of human actions (which is proper to religious mind) and a way of life based on the assumption that the unassisted human reason can by its own resources guide man's existence (which is proper to philosophy). As is well known, in Strauss's view, this opposition reaches its most radical expression when the tradition of revealed religion originated from biblical faith finally meets Greek philosophy. At this point, the spiritual and political life of the West becomes then dominated by the never resolved tension (in Strauss's eyes) between these two alternatives:

\footnotetext{
${ }^{27} \mathrm{NRH}$, p. 83-84. About the relationship between the ancestral and divine law, see also what Strauss says in his articles "The Mutual Influence of Theology and Philosophy," The Independent Journal of Philosophy, vol. 3 (1979): 111, and "Progress or Return? The Contemporary Crisis in Western Civilization," Modern Judaism, vol. 1 (1981): 41.

${ }^{28}$ Cf. STRAUSS, Leo. The City and Man (Chicago: University of Chicago Press, 1978 [1964]), p. 241 (hereafter cited as CM).

${ }_{29}$ LILLA, Mark. The Shipwrecked Mind, p. 47. These elements explain why the problem of religion occupies a fundamental place in Strauss's political reflection. See Corine Pelluchon, Leo Strauss: une autre raison, d'autres Lumières, p. 10.

${ }^{30}$ See NRH, p. 84-85, and "The Mutual Influence of Theology and Philosophy," p. 111-112.

${ }^{31}$ See, once again, Strauss's remarks in "Progress or Return?" p. 42, and Thomas Pangle's explanations in his introduction to $R C P R$, p. xvii.
} 
philosophic rationality on the one hand and revealed religion and its orthodoxy on the other, alternatives which are represented by two splendid and renowned cities: Athens and Jerusalem. ${ }^{32}$

This antagonism, which radically opposes the two most fundamental alternatives concerning the question of how men ought to live their lives - one that points to the need of divine guidance, another that intends to be based on unassisted reason -, represents what Strauss called, following Spinoza, "the theological-political problem."33 As Strauss tries to demonstrate in his lecture "On the Interpretation of Genesis," this problem (and the intellectual tension that belongs to it) would already have been noticed to some extent by the authors of the biblical text themselves, and a careful reading of the first chapters of the Genesis would show us that the fundamental prohibition conveyed by the Bible is a prohibition against "the temptation of philosophy," that is, a prohibition against the temptation of "autonomous knowledge." 34 Accordingly, Strauss says, the Bible "confronts us more clearly than any other book with this fundamental alternative: life in obedience to revelation, life in obedience, or life in human freedom, the latter being represented by the Greek philosophers." ${ }^{35}$

However it may be, what Strauss intends to make clear through these reflections is the fact that in the traditional civil society, where politics and religion are strongly integrated, the outbreak of philosophic activity, by unleashing the doubt of the political authority through the radical questioning of the official or orthodox opinions, necessarily brings with itself a contestation of the religion on which that authority is based. According to Strauss, this procedure is politically dangerous for both the philosopher and the society, and that is why the classical and medieval authors have tried to communicate their teachings with great care and discretion, accommodating (thanks to the use of esoteric writing) their discourse to the moral and religious opinions of the societies in which they lived. This means that although philosophy involves, on the private and reflexive level, an uncompromising questioning of the religious authority and divine law, on the public and social level things have to happen differently, and

\footnotetext{
${ }^{32}$ See Strauss's essay "Jerusalem and Athens," in SPPP, p.147-173. Cf. also NRH, p. 74-75, and "The Mutual Influence of Theology and Philosophy," p. 111-118. For a further explanation of this important topic of Strauss's work, see Steven B. Smith, "Leo Strauss: Between Athens and Jerusalem," p. 75-99, Ted V. MacAllister, Revolt Against Modernity, p. 26-27, and Daniel Tanguay, Leo Strauss: An Intellectual Biography, p. 144-192.

${ }^{33}$ As Ted MacAllister explains, "Strauss borrowed this phrase ["the theological-political problem"] from Spinoza's book. For Strauss, it is a very rich phrase, without a clear definition. It stands for a number of issues about the nature of politics and the role of religious beliefs in society." (Revolt Against Modernity, p. 282, n. 21). On this subject, see also Heinrich Meier, Leo Strauss and the Theologico-Political Problem, p. 3-28, and Thomas L. Pangle, Leo Strauss: An Introduction to his Thought and Intellectual Legacy, p. 26-28.

${ }^{34}$ STRAUSS, Leo. "On the Interpretation of Genesis," L'Homme, tome 21 (1981): p. 5-20

35 "On the Interpretation of Genesis," p. 19.
} 
philosophy must thus respect, for political reasons, the beliefs and teachings conveyed by established religion. In this sense, Strauss highlights a curious Farabi's teaching, which undoubtedly represents the attitude of traditional philosophy concerning religion, a teaching with which Strauss tacitly agrees. Simply put, this Farabian teaching argues that "conformity with the opinions of the religious community in which one is brought up, is a necessary qualification for the future philosopher." ${ }^{\prime 36}$

As one can see from the elements above explained, a respectful attitude towards the religious beliefs of a given society is then a fundamental component of the esoteric stratagem carried out by the ancient philosophers and their medieval disciples in their approach to the city. Evidently, this stratagem constitutes, after all, a rhetorical ruse, which aims simply to accommodate philosophic teaching to the doxastic atmosphere of political society. However, Strauss says, such a rhetorical ruse was seen by the classical authors as an indispensable proceeding to maintain political order since, for these authors, religion was, as it were, a social need. It follows that, from the classical perspective, philosophy must always adopt a prudential and circumspect demeanor towards religion, avoiding by all means appearing as an impious, atheist, and offensive activity. According to Strauss, this was the very essence of the "philosophic politics" developed by authors such as Plato and Cicero in Antiquity, "philosophic politics" that consisted first of all

in satisfying the city that the philosophers are not atheists, that they do not desecrate everything sacred to the city, that they reverence what the city reverences, that they are not subversive, in short, that they are not irresponsible adventures, but good citizens and even the best of citizens. This is the defense of philosophy which was required always and everywhere. ${ }^{37}$

From the point of view of the "philosophic politics" achieved by the classics, philosophy must therefore assume a pious appearance before the city and never offend the civic religion, hiding hence its subversive character vis-à-vis the authority of the divine law. It should be noted here that, according to Strauss, the main assumption behind this esoteric conception of philosophy is a deep skepticism about the possibility of making the burdensome intellectual requirements that characterize philosophy something that could become really diffuse or widespread, a deed that if accomplished would suppress in the long run the political rule of opinion over the human mind, transforming philosophy into the "element of society." Developing this approach, Strauss explains indeed that to the premodern thought philosophy is not accessible to everyone but only to a few, which means that a complete rationalization of human

\footnotetext{
${ }^{36}$ PAW, p. 17.

${ }^{37}$ OT, p. 206.
} 
life through the suppression of the intellectual cleavage that separates the vulgar and the wise is ultimately an impossible event. Now, insofar as a complete rationalization of human life is ultimately impossible, we must accordingly recognize that philosophy can never replace religion in the achievement of the task of guiding human life, which is but another way of saying that political society will always depend on some religious substratum to ensure its fundamental principles and values. Hence, the conclusion drawn by classical philosophy concerning the need to preserve all that traditional religious beliefs about justice and morality which, acting upon the behavior of citizens as a "noble rhetoric," contribute to the safeguarding of an ethical order that is indispensable to human life..$^{38}$ Of course, the basis of this teaching that radically restricts philosophy to an intellectual elite is the assertion of an anti-egalitarian anthropology, according to which reason is not a universal principle of human nature but rather a spiritual prerogative of a few, which means that the access to the sphere of autonomous thought and philosophy is by definition limited and not something that could be universally spread throughout the social structure. In a particular thought-provoking excerpt from his lecture "Reason and Revelation", Strauss states these elements by pointing out that

[t]his view of the relation of philosophy to life [the premodern view], i.e., to society, presupposes that philosophy is essentially the preserve of the very few individuals who are by nature fit for philosophy. The radical distinction between the wise and the vulgar is essential to the original concept of philosophy. The idea that philosophy as such could become the element of human life is wholly alien to all pre-modern thought. Plato demands that the philosophers should become kings; he does not demand that philosophy should become the ruler: in his perfect polity, only 2 or 3 individuals have any access whatever to philosophy; the large majority is guided by noble lies. ${ }^{39}$

It is interesting to note here, before closing the discussion of this topic, that for Strauss the attitude of prudence or wise circumspection regarding religion adopted by the ancients, which was motivated above all by political reasons, will be completely subverted by the moderns. In effect, through the belief in the possibility of the social dissemination of philosophy and

\footnotetext{
${ }^{38}$ TANGUAY, Daniel Leo Strauss: An Intellectual Biography, p. 97, explains this point of Strauss's understanding of classical and medieval teaching as follows: "Without healthy opinions on morality and justice, the city could not preserve itself [...] Given the impossibility of creating a rational and universal society, the city will always stand in need of a 'noble rhetoric' that rests on 'noble lies."'

${ }^{39}$ STRAUSS, Leo. "Reason and Revelation (1948)," p. 146-147. This same point is also emphasized by Strauss in $P A W$, p. 34. In this passage, Strauss asserts indeed that classical and medieval writers "believed that the gulf separating 'the wise' and 'the vulgar' was a basic fact of human nature which could not be influenced by any progress of popular education: philosophy, or science, was essentially a privilege of 'the few.' They were convinced that philosophy as such was suspect to, and hated by, the majority of men."
} 
science achieved by means of the mechanism of propaganda, the moderns will judge that it is possible to enlighten the people and rationalize the politics, limiting and even suppressing the powerful influence of revealed religion and its orthodoxy over human life. According to Strauss, this fact demonstrates that modern thought, whose most genuine expression is found in Enlightenment, has a radically "exoteric character," insofar as it gradually abandons the practice of concealment and secrecy adopted by traditional thought, and proposes itself the daring task of publicizing philosophic and scientific knowledge in order to promote the education of multitude. ${ }^{40}$ From the Straussian perspective, behind this change in philosophy's attitude towards society achieved by modern Enlightenment lies the view according to which the separation between the wise and the vulgar is not a permanent feature of human nature but a mere social phenomenon, susceptible as such to be modified through political action. ${ }^{41}$ Strauss explains that by taking this view for granted, modern philosophers will therefore think that the suppression of the influence of religious orthodoxy over human life is not only a feasible task but something politically necessary. And this is so, according to these philosophers, because the delusions and prejudices produced by religious beliefs constitute the major obstacle to the realization of the most urgent human interest - namely, to make man master and possessor of this world by creating a prosperous social order, based on the scientific control of nature. ${ }^{42}$ Strauss sees this intellectual hostility to religion as an essential component of the political and philosophic project of modernity, which allows him to consider that there is at the core of this project a virulent "anti-theological ire." ${ }^{43}$ What

\footnotetext{
${ }^{40}$ See what Strauss says about this subject in Philosophy and Law. Contributions to the Understanding of Maimonides and his predecessors. Translated with an introduction by Eve Adler (Albany: State University of New York Press, 1995), p. 102-103 (hereafter cited as PL). On Strauss's interpretation of modern Enlightenment as an "exoteric movement," aiming at "the universal emancipation" through the massive dissemination of philosophic and scientific knowledge, see Daniel Tanguay, "Leo Strauss et les Lumières modernes," in François Coppens, Leo Strauss. À quoi sert la philosophie politique, p. 47-66.

${ }^{41}$ See Joel L. Kraemer, "The Mediaeval Arabic Enlightenment," in Steven B. Smith, The Cambridge Companion to Leo Strauss, p. 165.

${ }^{42}$ This point is clarified by Strauss in the "Introduction" of $P L$, p. 21-39. About the "modern project" as a project to promote "the relief of man's estate" and to create a prosperous and free society, based on the scientific control of nature, see the "Preface" to CM, p. 3-4.

${ }^{43}$ Cf. TANGUAY, Daniel. Leo Strauss: An Intellectual Biography, p. 108: "Strauss characterized the spirit of the modern break as being moved essentially by anti-theological ire, by which he meant that the modern project was constructed over and against the old theological outlook that persuaded men to recognize laws of which they were not themselves the authors [emphasis in original]." See also Catherine Zuckert, "Strauss' Return to Premodern Thought," in Steven. B. Smith, The Cambridge Companion to Leo Strauss, p. 97. It is worth noting that, for Strauss, this attitude of hostility to religion, which expresses itself as "anti-theological ire," is already a moving force in the work of that author who is, on the philosophic domain, from the Straussian perspective, the true founder of modernity: Machiavelli. On this, see Strauss's remarks in Thoughts on Machiavelli (Chicago: University of Chicago Press, 1978 [1958]), p. 11-13; 174-223 (hereafter cited as TM), and in WPP, p. 41; 44. Taking these elements of the Straussian interpretation of Machiavelli into account, Corine Pelluchon, Leo Strauss. Une
} 
is more, insofar as this "anti-theological ire" is carried out by modern philosophers as an open and ostensible campaign against the social influence of the institutional religions, it acquires ipso facto a public character, which originates, in Strauss's view, a typically modern phenomenon - namely, political atheism. As Strauss himself explains in Natural Right and History, "'[b]oldness formerly was not the character of atheists as such' [...] Political atheism is a distinctly modern phenomenon. No premodern atheist doubted that social life required belief in, and worship of, God or gods." ${ }^{44}$

\section{The Political Teaching of the Ancient Philosophy and the Quest of the Best Regime}

As is evident from the observations made above, what Strauss intends to demonstrate through his formulations concerning the phenomenon of modern atheism is that the specificity of this atheism is found first and foremost in the fact that it has a public, exoteric character, which leads modern writers to abandon the idea of the social necessity of religion and advocate the belief that it is possible to base the political order on purely rational or philosophic principles, that is to say, without resorting to theological or religious beliefs. ${ }^{45}$ This means that modern thought intends to transform philosophy into the element of human life, based on the belief that "the harmony between philosophy and the people" can be brought about by "universal enlightenment." ${ }^{46}$ Well, in contrast to this bold political atheism advocated by the moderns, the classical writers (and also the medieval ones), as we have seen, adopted a more prudential posture concerning the religion of the city, judging that philosophic reason cannot be universalized. That is why for these writers religious beliefs will always play a necessary role in the preservation of political order. Now, considering these elements and the fact that "the exoteric teaching was the political philosophy" in its original meaning, one can therefore say that the kind of political philosophy elaborated by premodern authors was largely sympathetic to religion, or at least that the kind of political philosophy elaborated by premodern authors had no animosity towards religious beliefs.

\footnotetext{
autre raison, d'autres Lumières, p. 173, remarks that, in Strauss's view, there is a fundamental atheism at the heart of the new political teaching that the illustrious Florentine elaborates in deliberate opposition to the classics, an atheism that will seep into all later modern thought. Regarding Strauss's interpretation of the philosophic meaning of Machiavelli's work, cf. Ted V. McAllister, Revolt Against Modernity, p. 85-109.

${ }^{44} \mathrm{NRH}$, p. 169. Concerning the Straussian view about atheism and antagonism to religion as characteristics of modern thought, see also Catherine and Michael Zuckert, The Truth About Leo Strauss, p. 33-34.

${ }^{45}$ Cf. SMITH, Steven B. "Leo Strauss: Between Athens and Jerusalem," p. 82.

${ }^{46}$ CM, p. 37-38.
} 
Nevertheless, this is only the defensive aspect, so to speak, of classical political philosophy, to which, according to Strauss, a more assertive aspect was intrinsically connected. Strauss clarifies this point by saying that, since the political philosophy proposed by the ancient authors was directly related to the city, it had an eminently practical character and intended as such to provide a "right guidance" to the civic life. ${ }^{47}$ For Strauss, by developing political philosophy as a practical discipline, whose fundamental aim was to provide the "right guidance" of political life, classical philosophers sought, therefore, to act as true umpires in the political controversies that arise within the city (controversies which always presupposes thoughts on "goodness" and "justice"). This means that classical philosophers tried to act not as partisans but as wise advisers who, in the spirit of the "enlightened statesman", intended to solve the political conflicts among the citizens in order to guide the city to an "order as would be most in accordance with the requirements of human excellence." ${ }^{\prime 8}$ From the explanation of these points, Strauss draws our attention to the fact that classical political philosophy took a path opposed to that adopted by the contemporary political science, precisely because classical political philosophy assumed a radically practical character that led it to constitute itself as a wisdom capable of guiding the civic life to an excellent order. According to Strauss, in effect, as opposed to the "axiological neutrality" practiced by contemporary political science, which sets aside "value judgments" to elaborate an objective description of political and social phenomena, classical political philosophy systematically resorted to "value judgments" in the elaboration of its teachings, ignoring hence the precept of "axiological neutrality" that rules contemporary political science. In Strauss's own words, "[i]n contrast with present-day political science, or with well-known interpretations of present-day political science, classical political philosophy pursued practical aims and was guided by, and culminated in, 'value judgments."'49

Advancing in this line of investigation, the Straussian analysis further clarifies that since classical political philosophy was based on value judgments and intended to conduct political life towards an order "in accordance with the requirements of human excellence," classical political philosophers were irresistibly led to make the question of the best regime its guiding question. ${ }^{50}$ To explain this point, Strauss remarks that the concept of regime

\footnotetext{
${ }^{47}$ See $W P P$, p. 88.

${ }^{48}$ WPP, p. 80-81; 90.

${ }^{49} \mathrm{WPP}$, p. 88-89. Strauss further argues that the axiological neutrality advocated by present-day political science, neutrality based on the positivistic dichotomy between facts and values, makes this science ultimately unable to understand political phenomena as they are or in their true meaning since such phenomena are intrinsically valuative. On this subject, see Strauss's essay "Social Science and Humanism," in RCPR, p. 3-12, and the explanations afforded by Ted V. MacAllister, Revolt Against Modernity, p. 80-84.

${ }^{50}$ WPP, p. 34.
} 
(politeía, in the Greek language) is at the very core of classical political philosophy. However, one could justifiably ask, what did the classics understand, after all, by this concept? According to Strauss, in the context of classical thought, regime or politeía was conceived not as a merely legal phenomenon, related to what we today call "constitution," but rather as a much more fundamental and complex political fact, which embraces the customs, practices, and values of a given society. In this sense, Strauss asserts that, in the classical view, the regime is the fundamental principle from which the specific "way of life" of a given society comes out. Now, as the principle responsible for the specific "way of life" adopted by a given society, the regime is the primary political phenomenon and works, so to speak, as the source from which the laws (nómoi) and the characteristic form of government of a community ultimately arise. ${ }^{51}$ However, since there is a variety of regimes (kingship, aristocracy, oligarchy, etc.), each of them based on specific values whose claims are not entirely compatible with the claims that are characteristic of the values that rule other regimes, political thought is sooner or later inevitably confronted with the question concerning which regime is ultimately the best. Strauss highlights this decisive element of the classical political philosophy as follows:

There is a variety of regimes. Each regime raises a claim, explicitly or implicitly, which extends beyond the boundaries of any given society. These claims conflict, therefore, with each other. There is a variety of conflicting regimes. Thus the regimes themselves, and not any preoccupation of mere bystanders, force us to wonder which of the given conflicting regimes is better, and ultimately, which regime is the best. Classical political philosophy is guided by the question of the best regime..$^{52}$

To solve the question of the best regime, classical authors considered that it is necessary to understand first and foremost what the purpose of political life is. Now, as Strauss shows, for the classics, the ultimate end for which political society is established is neither security nor commerce, but the achievement of human perfection or virtue. Since virtue is the ultimate end of political life, the best regime is therefore the regime that enthrones virtue as the fundamental axiological principle that rules its customs and the organization of its political structures. As Strauss remarks, "[t]he classics had conceived of regimes (politeiai) not so much in terms of institutions as in terms of aims actually pursued by the community or its authoritative part. Accordingly, they regarded the best regime as that regime whose aim is virtue $[\ldots]^{\prime 53}$ This means that the best regime is ultimately aristocracy,

${ }^{51}$ NRH, p. 135-137. Cf. also WPP, p. 34.

${ }^{52}$ WPP, p. 34. In Strauss's view, the most evident point that marks the break between present-day social science and classical political philosophy is that the former has entirely abandoned the question of the best regime. As he says in WPP, "[ $t$ ]he most striking difference between classical political philosophy and present-day social science is that the latter is no longer concerned at all with what was the guiding question for the former: the question of the best political order." (WPP, p. 79).

${ }^{53} \mathrm{NRH}$, p. 193. 
insofar as aristocracy is the only regime that makes virtue explicitly and comprehensively the supreme goal of its whole political order. In Strauss's view, we find in these conceptions the two most fundamental tenets that theoretically unify classical political philosophy, tenets that provide to this philosophy its normative character - namely, virtue as the goal of political society and aristocracy as the best regime. In Strauss's words, "there is a fundamental and at the same time specific agreement among all classical political philosophers: the goal of political life is virtue, and the order most conducive to virtue is aristocratic republic, or else the mixed regime." ${ }^{54}$

Now, it is easy to see how classical political philosophy, through the elaboration of these ideas concerning the concept of the best regime, ultimately becomes a vigorous defense of the principles and values that rules the civic life, since these principles and values find an eloquent and paradigmatic expression of their true significance in the image of the most virtuous regime. Yet Strauss is quick to explain that, according to the classical authors, the actualization of the best regime, although it is not envisaged as an impossible event, is represented as something improbable and extremely difficult to take place, because for these authors this event depends, in the last analysis, on the occurrence of a rare and highly uncertain coincidence, i. e., the coincidence of political power and philosophy. This coincidence was seen by the ancient authors as the fundamental condition for the actualization of the best regime because this regime, as we have noted, was conceived as a political order based on the principle of virtue, and virtue, in turn, was determined by these authors as something subordinated directly or indirectly to wisdom. It follows that the best political order is the rule of that men that devote their lives to wisdom, i. e., the philosophers. Explaining this important point of the ancient political teaching, Strauss clarifies that " $t]$ he best regime is that in which the best men habitually rule, or aristocracy. Goodness is, if not identical with wisdom, at any rate dependent on wisdom: the best regime would seem to be the rule of the wise." ${ }^{55}$ The classics thought, however, that the actualization of this political rule of the wise, insofar as it requires the improbable coincidence of philosophy and political power, was not an event that could be controlled by the human will, but rather something that depends on a mysterious and imponderable phenomenon, over which man cannot exercise his sway - namely, chance. The ultimate lesson the ancient authors provide us concerning this central subject of their political teaching is therefore that, since only through chance could the best regime come into being, man is not the omnipotent master of his history. Strauss judges that thanks to this conception regarding the fundamental dependence of the actualization of the best regime on chance, classical political philosophy has always preserved a clear understanding of the limits and shortcomings of political society, never losing sight of the necessarily imperfect nature of

\footnotetext{
${ }^{54}$ WPP, p. 40.

${ }^{55} \mathrm{NRH}$, p. 140.
} 
man, a being who is neither a god nor a beast. He highlights and sums up these crucial points of classical political philosophy by saying that

[c]lassical political philosophy is guided by the question of the best regime. The actualization of the best regime depends on the coming together, on the coincidence of, things which have a natural tendency to move away from each other (e. g., on the coincidence of philosophy and political power); its actualization depends therefore on chance. Human nature is enslaved in so many ways that it is almost a miracle if an individual achieves the highest: what can one expect of society! The peculiar manner of being of the best regime - namely, its lacking actuality while being superior to all actual regimes - has its ultimate reason in the dual nature of man, in the fact that man is the in-between being: in between brutes and gods. ${ }^{56}$

\section{The Right Way of Life: Political Life versus Philosophic Life in Classical Political Philosophy}

For Strauss, the points outlined above regarding the problem of the best regime in classical political philosophy help us to understand why classical political philosophy has always adopted an attitude of sober moderation concerning the possibilities of reform and transformation of civil society, an attitude that was based, in this philosophy, on a solid acknowledgment of the essential limitations of the power of human action over the events that characterize actual political life. ${ }^{57}$ Strauss refers to this aspect of

${ }^{56}$ WPP, p. 34-35. On this matter, see also the following remarks proposed by Strauss in NRH: "[...] the best regime, as the classics understand it, is not only most desirable; it is also meant to be feasible or possible, i. e., possible on earth. It is both desirable and possible because it is according to nature [...] Yet, while the best regime is possible, its actualization is by no means necessary. Its actualization is very difficult, hence improbable, even extremely improbable. For man does not control the conditions under which it could become actual. Its actualization depends on chance. The best regime, which is according to nature, was perhaps never actual; there is no reason to assume that it is actual at present; and it may never become actual. It is of its essence to exist in speech as distinguished from deed." (NRH, p. 139). It is worth noting here that for Strauss, in addition to the change in the attitude towards the social role of religion, another fundamental point that helps us to understand the modern rupture vis-à-vis the classical political philosophy is precisely the fact that the moderns abandon all these conceptions concerning the best regime and its improbable actualization. According to Strauss, this is what one can see in an outstanding way, for example, in Machiavelli, the author whose work inaugurates, from the Straussian perspective, as we have seen, modernity on the philosophic level. Indeed, in the Straussian explanation, Machiavelli, intending to develop a new political realism that would be uncompromised and radical, deliberately rejects both the concern for the best regime and the idea that chance is something that cannot be controlled by man. See Strauss explanations in WPP, p. 41, and OT, p. 106, n. 5.

57 Thomas L. Pangle highlights this topic of Strauss's analysis of the meaning of classical political philosophy, observing that, in Strauss's view, "classical political philosophy conceives the 'best regime' not as an 'ideal' to be realized, or even as something to be approached and worked toward; the elaboration of the best regime is intended, rather, as a subtly playful thought-experiment meant to reveal the limitations on what we can expect from all actual political life." (Leo Strauss: An Introduction to his Thought and Intellectual Legacy, p. 46). 
classical political philosophy by saying that it "is free from all fanaticism because it knows that evil cannot be eradicated and therefore that one's expectations from politics must be moderate. The spirit which animates it may be described as serenity or sublime sobriety." ${ }^{58}$

It is essential now to remark that Strauss thinks that the need felt by the ancient authors to promote political philosophy as an exoteric rhetoric procedure, with a view not only to protecting themselves from persecution but also to defending the values of political life, ultimately derives from the fact that these authors recognized their original dependence on political society. Now, recognizing their original dependence on political society, these authors were led to develop a deep interest in not undermining the civic order to which they belonged as citizens. The fundamental point here, which underlies this aspect of the Straussian interpretation of classical philosophy, is the idea that ancient philosophers had perfectly realized that they necessarily live, like any other men, in cities and cannot hence turn their backs on the societies to which they belong, taking refuge for good, as it were, on the contemplative sphere. As one can easily see, these ideas, which give philosophy a necessarily political dimension, are strictly connected in classical philosophy with another fundamental teaching advocated by the ancient authors - namely, the teaching about the political or social nature of man, which intends to point out the undisputable fact that man originally needs the city or civil society to actualize his humanity. In Natural Right and History, explaining the character of classical natural right, Strauss refers to this fundamental teaching of the classics and remarks that for them,

[m] an is by nature a social being. He is so constituted that he cannot live, or live well, except by living with others. Since it is reason or speech that distinguishes him from other animals, and speech is communication, man is social in a more radical sense than any other social animal: humanity itself is sociality. ${ }^{59}$

So, if it is true that man has a social or political nature, or, to use Strauss's expression, if "humanity itself is sociality," then it can be said that it is inevitable that philosophy become, to some extent, "political philosophy," which is equivalent to saying that philosophy must therefore assume a public dimension - an idea that Strauss, by the way, fully endorses. Gourevitch and Roth, intending to draw our attention to this aspect of

\footnotetext{
${ }^{58}$ WPP, p. 28. The attitude of "sublime sobriety" adopted by classical thought regarding politics contrasts, according to Strauss, with the voluntarist and even revolutionary attitude of modern thought. For Strauss, in effect, modern thought, by absorbing and seeking to take to the last consequences the Machiavellian teaching concerning the human control of chance, will believe that it is possible to bring about the complete rationalization of politics and achieve thereby the final harmonization of philosophy and civil society, abolishing, as a result, all evils from history. Concerning this subject, see Allan Bloom, "Leo Strauss. September 20, 1889-October 18, 1973," p. 389, and Steven B. Smith, "Leo Strauss: Between Athens and Jerusalem," p. 81-82.
}

${ }^{59} \mathrm{NRH}$, p. 129. 
Straussian thought, explain that "Strauss fully grants, indeed he stresses that philosophy is inevitably political, if only because philosophers live in political communities." ${ }^{60}$ For Strauss, this means that politics has for men, in a sense, a primordial character and constitutes as such the necessary starting point from which philosophic thought must begin. The basic idea that Strauss aims to convey concerning this topic is that, given the political dependence of man on society, philosophy cannot ignore the primeval domain of the city where it is originally grounded and has thus to meet the demands concerning morality that are imposed on civic life, taking as the raw material of its dialectical researches the opinions that keep political life in motion. ${ }^{61}$ Be this as it may, in the context of the Straussian interpretation, it was for taking the elements mentioned above into account that classical authors tried to act with the utmost rhetorical caution in communicating their heterodox teachings and decided to behave as responsible and law-abiding citizens, not as subversives, hiding the "harmful truths" that would endanger the moral order without which society cannot subsist. Needless to say, Strauss also agrees with this judicious "economy of truth" practiced by the premodern writers in their approach to the city and sees it as a wise strategy to be used by the philosopher when public communication, or communication with the political society, is required. In his lecture "Reason and Revelation", he states this point as follows:

The philosopher has to meet the legitimate claims of society or to shoulder his own responsibility as a citizen. He does this by refraining from publicly teaching what he considers the truth in so far as the truth could become dangerous to society. He hides his true teaching behind a socially useful exoteric teaching. ${ }^{62}$

As this quotation shows us, according to Strauss, the philosopher, by recognizing the demands of social life and his civic duties as a member of the political community, must thus "hide his true teaching" and write with "political responsibility," never losing sight of the possible impacts of his teachings on the city. ${ }^{63}$ In doing so, the philosopher will accordingly,

${ }^{60}$ GOUREVITCH, Victor and ROTH, Michael S. "Introduction," in OT, p. xviii.

${ }^{61}$ WPP, p. 92. It is in the light of these remarks that one must understand the Straussian conception of political philosophy as "first philosophy." Cf. Steven B. Smith, "Philosophy as a Way of Life: The Case of Leo Strauss," p. 65-69, and Corine Pelluchon, Leo Strauss. Une autre raison, d'autres Lumières, p. 22.

62 "Reason and Revelation (1948)," in H. Meier, Leo Strauss and the Theologico-Political Problem, p. 146.

${ }_{63}$ On the "political responsibility" of the philosopher, see Nathan Tarcov and Thomas L. Pangle, "Epilogue. Leo Strauss and the History of Political Philosophy," in History of Political Philosophy, ed. Leo Strauss; Joseph Cropsey (Chicago: University of Chicago Press, 1987 [1963]), p. 914-915. Cf. also the explanations afforded by Steven B. Smith, "Philosophy as Way of Life: The Case of Leo Strauss," p. 72. Smith remarks that, according to Strauss, the philosopher's responsibility to the city consists in the fact that the philosopher, "recognizing that philosophy can only take place within the context of the city, must show a decent respect for the opinions on which the city is based." 
in Strauss's eyes, keep the exercise of philosophy as a strictly esoteric activity, whose intellectual procedures are accessible only to a few, at the same time that he will seek to foster on the exoteric level the values that are indispensable to the political order. ${ }^{64}$ As we have seen, this is precisely what the classical philosophers would have done with great mastery, thanks to the use of the literary technique of esotericism.

However, this is only one side of the question, because for Strauss, although classical philosophers have recognized the fundamental character of political life and, in so doing, were led to develop political philosophy in the sense mentioned above, they did not see the realm of politics as the supreme horizon of human life. Strauss explains, indeed, that for these philosophers the supreme horizon of human life was by no means politics but philosophy, and philosophy was conceived by them as a theoretical activity whose aim was precisely to transcend the conventional beliefs of civil society in search of the private knowledge of the highest object of human wisdom: the first causes, or principles, of the whole, which manifest themselves in the eternal order of nature. Strauss considers that this overcoming of all civic beliefs in order to achieve the knowledge about the whole was precisely what the ancient philosophers tried to carry out, and that is why philosophy remained to them, under its exoteric political jacket, a fundamentally contemplative and even trans-political activity. It is in the light of these elements, which makes clear the essentially private character of philosophic knowledge, that we must understand Strauss's statement that for the Greek thinkers "contemplation is a trans- or asocial possibility." ${ }^{65}$

We undoubtedly find here, according to Strauss, a fundamental point in the characterization of classical thought, namely, its final understanding of the philosophic life as an essentially contemplative life, whose exercise, aiming at the knowledge of the eternal order of nature, leads the philosopher's mind irresistibly beyond the parochial limits of the city. ${ }^{66}$ What is more, the ancient writers, Strauss says, in the very act in which they determine philosophy as an essentially contemplative and esoteric activity, assert at the same time that philosophy thus understood consti-

\footnotetext{
${ }^{64}$ This means, as Steven B. Smith pointed out, that for Strauss "the philosopher's public responsibilities are entirely exoteric." ("Philosophy as Way of Life: The Case of Leo Strauss," p. 72). On this subject, see also the explanations proposed by Catherine and Michael Zuckert, The Truth About Leo Strauss, p. 44-45.

65 "Progress or Return?" p. 37.

${ }^{66}$ In OT, p. 198-199; 212-213, Strauss explains that this conception advocated by the classic authors concerning the trans-political nature of philosophy involves the idea that the philosopher's mind, in its search of knowledge of the eternal order, can liberate itself from the paltry human concerns that characterize political life and reach a cosmic point of view from which the philosopher can observe all human things with serene disdain, which converts him into a new kind of citizen: the citizen whose citizenship is defined by his noetic integration into the whole.
} 
tutes the final answer to the question concerning the right way of life, or, to put it another way, concerning the most virtuous life, representing as such the highest happiness (eudaimonia, in the Greek language) available to man: the noetic happiness produced by the intellect, the most excellent human faculty. According to Strauss, this means that, for the ancients, what constitutes the very aim of political life, i. e., virtue or excellence, cannot be achieved within the limits of political life itself, but only by a type of intellectual activity that transcends political life. Strauss clarifies further that this paradox is the ultimate outcome of classical political philosophy and remarks that all the writings of the ancient philosophers seek, in the last analysis, to point out in one way or another to this truth, which is just another way of saying that, in the context of classical philosophy, the ultimate intent of political philosophy consists paradoxically in trying to demonstrate the supremacy of philosophic life. To highlight this truly decisive aspect of ancient thought, Strauss explains in his essay "On Classical Political Philosophy" that, according to the classical authors, the philosopher, in his effort to answer the question about human virtue or excellence,

is ultimately compelled to transcend not merely the dimension of common opinion, of political opinion, but the dimension of political life as such; for he is led to realize that the ultimate aim of political life cannot be reached by political life, but only by a life devoted to contemplation, to philosophy. This finding is of crucial importance for political life, to all political action and all political planning. Moreover, it implies that the highest subject of political philosophy is the philosophic life: philosophy - not as a teaching or as a body of knowledge, but as a way of life - offers, as it were, the solution to the problem that keeps political life in motion. Ultimately, political philosophy transforms itself into a discipline that is no longer concerned with political things in the ordinary sense of the term $[\ldots] .{ }^{67}$

It is worth noting here that this solution proposed by the ancient thought, which identifies the perfect human happiness with the theoretical life peculiar to philosophy, is one that will be adopted by Strauss himself, so that Straussian position can be characterized ultimately, as Tanguay remarks, as "a radical and elitist form of intellectual eudaimonism." ${ }^{68}$ However it may be, what Strauss intends to make clear through the development of his analyses about the character of classical political philosophy is that classical political philosophy, from the utterances concerning the perfect happiness produced by philosophy, comes to a climax, as it were, by asserting the existence of an ultimate end of man situated above the city. Making such an assertion, classical philosophy cannot but proclaim therefore the essential inferiority of political life in relation to philosophic life, i. e., in relation to the life dedicated to the pursuit of contemplation of

${ }^{67}$ WPP, p. 89.

${ }^{68}$ TANGUAY, Daniel. Leo Strauss: An Intellectual Biography, p. 91. 
the eternal truth. In Strauss's words, "according to the classics, political life as such is essentially inferior in dignity to the philosophic life." ${ }^{69}$ This means that, for the ancient authors, politics does not exhaust everything that concerns human life, or, more precisely, that politics is not the highest activity of man since there is a way of life superior to the life in the city: the life of the philosopher, which, requiring the achievement of the most excellent capacity of the human soul, i. e., intellectual capacity, is the most elevated perfection to which man can aspire. As Strauss explains in Thoughts on Machiavelli,

[t]he classics understood the moral-political phenomena in the light of man's highest virtue or perfection, the life of the philosopher or the contemplative life $[\ldots]$ philosophy transcends the city, and the worth of the city depends ultimately on its openness, or deference, to philosophy. ${ }^{70}$

However, that is not all. In the Straussian explanation, to the extent that morality is intrinsically associated with political life as a fundamental component of it, the supremacy of philosophic life over political life proclaimed by the classics means that originally life dedicated to philosophy is conceived not only as something that transcends political life but also as something that transcends morality itself - a surprising corollary that Strauss does not hesitate to express as follows:

According to its original meaning, philosophy is the right way of life, the happiness of man. All other human pursuits are accordingly considered fundamentally defective, or forms of human misery, however splendid. The moral life as moral life is not the philosophic life: for the philosopher, morality is nothing but the condition or the by-product of philosophizing, and not something valuable in itself. Philosophy is not only trans-social and trans-religious, but trans-moral as well. ${ }^{71}$

Although surprising, this view advocated by the classics about the inferiority of morality in relation to philosophic life is, in Strauss's view, a perfectly coherent result of their position regarding the understanding of the relationships between philosophic and political life. If philosophic life, or the life dedicated to the search of knowledge of the eternal order, is indeed above political life, insofar as such life constitutes a bios more perfect and happier than that which is proper to the political dimension, and if the principles of morality are substantially articulated to the city, philosophy, by transcending the city, transcends by the same token morality. It follows from this view that, according to classical teaching, traditional moral virtue is therefore a principle that only acquires its full justification from its subordination to what transcends it and which constitutes the

\footnotetext{
${ }^{69} N R H$, p. 145 . See also OT, p. 198-200.

${ }^{70}$ TM, p. 295-296.

71 “Reason and Revelation (1948)," p. 147.
} 
ultimate perfection of the human mind: the noetic or intellectual excellence achieved by philosophy. ${ }^{72}$

For Strauss, these classical teachings about the supremacy of philosophic contemplation over political and moral life bring to light a decisive element in the configuration of ancient thought, namely, its idea of philosophy as a noetic experience that has a transcendence in relation to what is politically established and that, being able to escape the chains of historical and social conditioning, can grasp something eternal, as the Platonic allegory of the cave intends to point out. ${ }^{73}$ According to the classics, this means that the philosophic reason is not a mere intellectual epiphenomenon of the political and moral order existing in a particular society but a spiritual power that possesses true autonomy in the face of that order, being able as such to go beyond its historical limits. In Strauss's view, here lies the most fundamental claim present in the original position of philosophy, just as that position was articulated by ancient thought.

Well, the essential point that Strauss intends to highlight from these elements is that this philosophic claim endorsed by the classic authors, by asserting the capacity of transcendence of human mind vis-à-vis history, constitutes a legitimate theoretical alternative to what is perhaps the most powerful intellectual movement of our days: historicism. According to Strauss, historicism is based, in effect, on the premise that asserts the fundamental historicity of human thought, and, from that premise, historicism asserts the essential and hence insurmountable dependence of all values and philosophic teachings on the cultural and social structures existing at a particular historical moment. For Strauss, the conception developed by classical philosophy is defined by a complete opposition to this radical immanentization of thought advocated by historicism. The ancient philosophers, Strauss says, did not ignore, of course, the so-called "experience of history" that is brought up by modern and contemporary historicists as the theoretical basis for their statements. However, unlike modern and contemporary historicists, ancient philosophers did not believe that the human mind would be definitively trapped within the limits of historical immanence. On the contrary, for them, as the Platonic allegory of the

\footnotetext{
${ }^{72}$ In NRH, p. 151, Strauss explains this point as follows: "If striving for knowledge of the eternal truth is the ultimate end of man, justice and moral virtue in general can be fully legitimate only by the fact that they are required for the sake of that ultimate end or that they are conditions of philosophic life. From this point of view the man who is merely just or moral without being a philosopher appears as a mutilated human being."

${ }^{73}$ See, again, what Strauss says in NRH, p. 11-12. Strauss understood the Platonic allegory of the cave as a powerful image of man's fundamental situation concerning social and political life. Cf. Allan Bloom, “Leo Strauss. September 20, 1889-October 18, 1973," p. 378: "Leo Strauss believed that the Platonic image of the cave described the essential human condition. All men begin, and most men end, as prisoners of the authoritative opinions of their time and place. Education is a liberation from those bonds, the ascent to a standpoint from which the cave can be seen for what it is [emphasis in original]."
} 
cave shows us, the philosophic experience was an experience of liberation, and this experience would teach us that reason can detach itself from the chains of historicity and therefore from the spiritual yoke of authorized opinions of a certain social order, achieving a noetic freedom that would lead our soul beyond the parochial domain of politics. ${ }^{74}$

\section{Conclusion}

The analysis of Strauss's texts carried out in the previous pages demonstrates that the attempt to understand in a clear way how philosophy was conceived in the context of ancient thought constituted, without a doubt, a crucial concern of the Straussian research. However, as we explained at the beginning of this article, this intellectual enterprise was not for Strauss a work of purely historiographic character, motivated by mere archaeological concern and whose scope would be hence limited to the field of conventional scholarship. On the contrary, as we also made clear at the beginning of our exposition, Strauss develops a dense and sophisticated approach to the sources of ancient thought in a genuinely reflective way and inspired by a deeply philosophic intention - namely, the intention to recover and bring to light again what was the original position of philosophy, as it manifests itself in the works of the classical authors.

Roughly speaking, what Strauss intends to do through the realization of this intellectual and hermeneutical procedure is to comprehend how the type of rationality present in that original position still retains some significance for us, offering as such a legitimate alternative to the main expressions of modern and contemporary thought. Now, by achieving this proposal, Strauss is successful in showing us that philosophy was for classical authors, first of all, a way of life and a complex intellectual practice, capable of carrying out the combination of the most daring reflective radicalism with an austere political sobriety. From the Straussian perspective, the most impressive result of this combination of reflective radicalism with political sobriety proposed by classical authors is precisely the creation of classical political philosophy and that rhetorical device which is its most typical literary product: the art of esoteric writing. Strauss demonstrates indeed that, in the view of ancient thinkers, the intellectual experience of philosophy is essentially disruptive, prompted by an uncompromising examination of authorized opinions and having as its main scope the achievement of knowledge of the eternal order. However, according to Strauss, the ancients understood very well that, since "opinion is the element of society," philosophic questioning assumes, by virtue of its very nature, a politically problematic character, giving rise to a spiritual rebellion that is

\footnotetext{
${ }^{74}$ Strauss discusses the historicist thesis in comparison with the classic position in NRH, p. 9-34.
} 
dangerous for both the philosopher and society. In the Straussian scheme, it is from the perception of this politically problematic character of philosophy that the literary technique of esotericism comes up in classical philosophy, and this technique was conceived as a rhetorical ruse devised to protect both the philosopher against the risk of political persecution and the city and its beliefs against the disturbing effects of philosophic questioning. For Strauss, as we have seen, this use of esotericism in ancient philosophy is ultimately confused with political philosophy itself, and political philosophy, in turn, was understood originally, by the classical authors, not as the philosophic treatment of politics but as the political, or popular, presentation of philosophy, i. e., as the presentation of philosophy in accordance with the beliefs and values of the city. Strauss's great insight here is that thanks to political philosophy thus understood, ancient thought has become politically responsible and carry out a consistent defense of the city and its institutions (especially religion), while preserving, at the same time, philosophic activity as an esoteric practice that, by achieving a radical intellectual questioning, operates that noetic rupture with authorized opinions capable of leading the philosopher's mind beyond the civic limits and towards the contemplation of the eternal order.

In Strauss's eyes, this approach achieved by the classics, which manifests the original position of philosophy, still retains a theoretical interest today because it provides us with elements, as indicated above, to think about an alternative to historicism, a philosophic movement that, as we explained, Strauss judged to be perhaps the most powerful of our time and according to which there would be a fundamental historicity of all human thought. Indeed, showing us that philosophy is originally a disruptive and subversive activity, which accomplishes the systematic questioning of the opinions and beliefs sanctioned by the authority of a community, ancient thought reveals to us by the same token that philosophic activity in its most authentic expression always presupposes a movement of liberation and spiritual independence vis-à-vis the dogmas and values of political society. This means that, according to the teaching proposed by ancient thought, genuine philosophic activity can never be reduced, as the historicist claims, to a mere intellectual by-product of a historical context. Now, making this manifest, classical authors bring the viscerally extemporaneous character of philosophy to the fore, and this philosophical extemporaneity can be seen as a result of the capacity of philosophic reason to criticize and hence transcend what is merely given in a particular time and place. From this perspective, philosophy is not merely the conceptual elaboration of its own time, as Hegel intended, ${ }^{75}$ but something that can confront its own time and ultimately surpass it.

${ }^{75}$ Cf. HEGEL, George W. Outlines of Philosophy of Right. Translated by T. M. Knox. Revised, edited, and introduced by Stephen Houlgate (Oxford: Oxford University Press, 2008), p. 15: "Whatever happens, every individual is a child of his time; so philosophy too is its own time apprehended in thoughts." 
Strauss further thinks that the classical approach has yet something to tell us because it also points out how is possible to reconcile this radical autonomy or intellectual independence that is characteristic of philosophy with the undeniable political dimension of human life. In this regard, Strauss's idea is that classical philosophy, keeping the true philosophic teaching as something hidden or esoteric, teaches us how to avoid what is the greatest danger that lurks philosophy in our time, namely, ideologization, a danger that, when materialized, deprives philosophy of its noetic freedom, reducing it to a mere instrument for defending the interests of parties and political movements in their relentless struggle for power. ${ }^{76}$ From the Straussian perspective, this phenomenon results directly from the project of rationalization of political life proposed by modern Enlightenment, a project that, in the name of the social dissemination of philosophic reason and the conversion of philosophy into the agent of the historical changes that will lead humanity to a state of prosperity and freedom, ends up debasing philosophy to the condition of a simple tool of political action. ${ }^{77}$ Strauss says that, in opposition to this ideologization resulting from the political ambitions of modern rationalism, classical thought points to the model of an alternative rationalism which, based on the idea that philosophy is a type of knowledge necessarily restricted to a few and on the suspicion concerning the daydreams of omnipotence concerning human action, keeps a skeptical distance from the dismal illusions of political voluntarism. In doing so, classical thought recognizes therefore that the specific task of philosophy consists ultimately not in the complete politicization of itself but in the exercise of an entirely free and disruptive noetic activity which, taking the mind of the man who accomplishes it beyond the narrow borders of political life, has but one compromise: the intransigent search of the truth.

Endereço do Autor:

Rua Ouro Branco, 114 - Complemento C.

Bairro Recanto da Serra

36325-000 Tiradentes - MG

richardromeiro@hotmail.com

\footnotetext{
${ }^{76}$ About the Straussian view concerning this danger, see Steven B. Smith, "Philosophy as a Way of Life: The Case of Leo Strauss," p. 71.

77 See Strauss's remarks in NRH, p. 34.
} 